\title{
Schizofreni og vold - kan man forutsi voldelig atferd?
}

\author{
Voldelig atferd hos mennesker kan aldri forutsies som en kategorisk spådom, men det finnes kriterier for \\ å anslå den gruppebaserte voldsrisikoen. For psykotiske pasienter er det dokumentert at noen diagnosetyper \\ innebærer forhøyet risiko for voldsutøvelse. Schizofreni, spesielt paranoid type, er den viktigste av disse. \\ Dette må ikke føre til stigmatisering av denne pasientgruppen.
}

Bedømmelse av voldsrisiko er viktig for å forebygge voldelig atferd - individuell vold mot både en selv og andre. Psykiatrien har rutiner og prosedyrer for begge formål. Når det gjelder vold mot andre, har risikovurderingen de siste 30 år gått inn $i$ et mer gjennomarbeidet spor, bl.a. ved bruk av strukturerte sjekklister. Vi publiserte en oversiktsartikkel om dette i Tidsskriftet i 2001 (1). I store linjer beskrives her fortsatt dagens vurderinger og repertoar av hjelpemidler, selv om bruken av sjekklister har økt betydelig de siste ti år, også i Norge. Det er viktig å understreke at sjekklistene ikke på noen måte er patognomoniske laboratorieprøver for konkret vold i nær eller fjernere fremtid, de er kun hjelpemidler for den endelige kliniske og fornuftsmessige vurdering av et risikonivå. Forekomsten av vold ved forskjellige diagnostiske typer av psykisk sykdom og avvik er av betydning for risikovurderingen, og jeg vil kort presentere dette i denne kommentaren.

\section{Økt voldsrisiko ved psykose}

Både definitiv psykisk sykdom, særlig psykoser, og avvik, særlig personlighetsforstyrrelser med utagering, gir økt tendens til voldsutøvelse. De aller fleste alvorlige voldshandlinger utøves av ikke-psykotiske personer, herunder de ovenfornevnte med personlighetsforstyrrelse, og - det må huskes - ofte også av personer som ikke gis noen diagnose fra offisiell psykiatrisk diagnoseliste. Likevel er schizofreni og beslektede psykotiske lidelser av vesentlig betydning. Ledsagende rusmisbruk hos alle de ovenfornevnte kategorier er en særdeles uheldig forsterkende faktor.

Historisk har sammenhengen mellom det som ble kalt sinnssykdom (oftest sammenfallende med aktiv psykose) og vold/farlighet vært vektlagt, bl.a. hos Platon og Shakespeare. I moderne tid går sammenhengen igjen i mediene, litteraturen og folkemeningen. På psykiatrifaglig hold har det i omtrent 50 år vært diskusjon om voldsrisikoen hos psykotiske. Denne diskusjonen er meget godt og stringent fremstilt i en oversiktsartikkel i 2007 (2). Her fremkommer det at det av fremtredende forskere i en lengre periode, frem til midten av 1980 årene, ble hevdet at psykose i seg selv ikke var noen risikofaktor - alt kunne forklares av bostedsområde, sosial klasse, personlighet, rase og rus (3). Samme forskergruppe måtte i løpet av det kommende tiåret revidere sin tidligere (trolig humanistisk/ ideologisk baserte) holdning og erklære at psykose i en del sammenhenger var en vesentlig selvstendig risikofaktor.

I dag er dette påvist i en lang rekke studier, og i en svært omfattende metaanalyse fra 2009 (4) understrekes og differensieres det i hovedsak slik: Psykose som helhet er signifikant assosiert med 50-70\% økning av voldsrisikoen. Innenfor psykosefeltet er det meget stor spredning - schizofreni (særlig paranoid type) og ikke-schizofren paranoid psykose frembyr økt voldsrisiko, med en oddsratio på 4 eller mer i forhold til normalbefolkningen. andre studier i et finsk arbeid over schizofrene drapsmenn (6), der den relative risikoen ble funnet å øke fra 7 uten rus til 17 med rus.

\section{God effekt av behandling}

Begrepet «perceived threat and control override» (TCO) (7) står for en tilstand der pasienten i psykotisk sammenheng opplever at andre kontrollerer tankene, ved enten å stjele dem eller direkte implantere sine tanker i pasientens sinn, og intrigerer mot en, forfølger en og ønsker å skade en fysisk. Videre er tilstanden oftest ledsaget av sterkt emosjonelt ubehag ledsaget av økt autonom beredskap. Dette leder til at en grunnleggende kontroll over voldsimpulser kan brytes ned. Avblekede former

\section{«Voldsrisikovurdering hos psykiatriske pasienter eller mentalt avvikende personer utenfor psykisk helsevern er en viktig oppgave for psykiatrisk skolerte fagfolk»}

Dette reflekteres tydelig for norske forhold i den gruppen på 84 personer som i femårsperioden 2002-07 på grunn av meget alvorlig(e) voldshandling(er) ble dømt til tvungent psykisk helsevern som utilregnelige med psykotisk lidelse. Disse ble vurdert av undertegnede for det såkalte Mæland-utvalgets rapport (5). Av hoveddiagnosene for de 84 dømte utgjorde paranoid schizofreni $59 \%$, annen schizofreni og schizoaffektiv psykose $11 \%$, paranoid psykose (ikke-schizofren) $18 \%$ og øvrige psykoser (hvorav bare $2 \%$ primær rusutløst psykose) $11 \%$. Her kommer det tydelig frem at ikke bare schizofreni, men særlig den paranoide utgave av denne samt andre paranoide psykoser (til sammen $77 \%$ av hoveddiagnosene) hadde en fremtredende assosiasjon til vold. Når det gjaldt rusens betydning for vold hos psykotiske, forelå det komorbid rustilstand og/eller rus i tiden for gjerningen hos nær halvparten, men dette utgjorde altså ikke hoveddiagnoser. At komorbiditet med rus potenserer voldsrisikoen, vises blant mange av dette kan også ses hos ikke-psykotiske personer med paranoid utforming, men særlig hos psykotiske kan det ses som en hovedmekanisme bak voldsutøvelsen. Videre kan det være det viktigste elementet i de etiske og juridiske grunner til å godkjenne strafferettslig utilregnelighet (insanity excuse) ved alvorlige voldshandlinger hos psykotiske mennesker, og da ved å anerkjenne disse som et desperat selvforsvar.

Selv om noen, fortrinnsvis folk som er uten behandlingserfaring med alvorlige psykoser, har stilt spørsmål ved effekten av antipsykotisk medikamentell behandling generelt, er det konsensus om at denne typen psykotiske symptomer er godt tilgjengelig for slik terapi. Dette legger et vesentlig ansvar på helsevesenets beredskap for rasjonell og hurtig behandling ved alvorlige paranoid-psykotiske lidelser. Samme ansvar understrekes bl.a. i en metaanalyse (8) der man sammenlikner drapsrater hos førstegangspsykotiske før og etter innsetting av behandlingsopplegg. 


\section{Andre lidelser innebærer lavere voldsrisiko}

Voldsrisikovurdering hos psykiatriske pasienter eller mentalt avvikende personer utenfor psykisk helsevern er en viktig oppgave for psykiatrisk skolerte fagfolk. Det er viktig å gjenta at psykisk lidelse som helhet ikke gir noen økning av risikoen. Selv om psykose generelt medfører moderat forhøyet risiko (4), er en rekke ikke-psykotiske subjektive lidelser forbundet med lavere voldsrisiko enn i gjennomsnittsbefolkningen. Særlig gjelder det lidelser preget av unnvikende, overhemmede og oversamvittighetsfulle trekk. Psykiatriens hovedberedskap må altså gjelde overfor de psykosetypene som er presisert over (4). I tillegg vil en del personer med personlighetsforstyrrelser med utagering og/eller med rusmisbruk utgjøre behandlings- og kontrolloppgaver for det psykiske helsevern. Imidlertid er dette oppgaver der det juridisk kreves frivillig deltakelse, noe mange av disse mangler motivering for.

\section{Pål Hartvig}

paal.hartvig@kompetanse-senteret.no Kompetansesenter for sikkerhets-, fengselsog rettspsykiatri

Oslo universitetssykehus

Pål Hartvig (f. 1936) er spesialist i psykiatri og dr.philos. Han har lang og bredspektret erfaring i kliniske og administrative stillinger. Fra 2000 har han vært forsker ved Kompetansesenter for sikkerhets-, fengsels- og rettspsykiatri, Oslo universitetssykehus.

Forfatter har fylt ut ICMJE-skjemaet og oppgir ingen interessekonflikter.

\section{Litteratur}

1. Hartvig P, Alfarnes SA, Østberg B. Risikovurdering for voldelig atferd - bruk av sjekklister. Tidsskr Nor Lægeforen 2001; 121: 3431-4.

2. Harris A, Lurigio AJ. Mental illness and violence: A brief review of research and assessment strategies. Aggress Violent Behav 2007; 12: 542-51.

3. Monahan J, Stedman H. Crime and mental disorder: an epidemiological approach. I: Morris N, Tonry M, red. Crime and justice: an annual review of research. Chicago, IL: University of Chicago Press, 1983: 145-89.

4. Douglas KS, Guy LS, Hart SD. Psychosis as a risk factor for violence to others: a meta-analysis. Psychol Bull 2009; 135: 679-706.

5. Etterkontroll av reglene om strafferettslig utilregnelighet, strafferettslige særreaksjoner og forvaring. Rapport. Oslo: Justis- og politidepartementet, 2008: 133-142

6. Eronen M, Hakola P, Tiihonen J. Mental disorders and homicidal behavior in Finland. Arch Gen Psychiatry 1996; 53: 497-501.

7. Bjørkly S, Havik OE. TCO symptom as markers of violence in a sample of severely violent psychiatric inpatients. Int J Forensic Ment Health 2003. 2: 87-97.

8. Nielssen O, Large M. Rates of homicide during the first episode of psychosis and after treatment a systematic review and meta-analysis. Schizophr Bull 2010; 36: 702-12 